\title{
Utjecaj istraživača na rezultate kinetičke analize toplinske razgradnje polimera
}

\author{
M. Erceg, M. Jakići I. Krešić
}

Sveučilište u Splitu, Kemijsko-tehnološki fakultet, Ruđera Boškovića 35, 21000 Split, Hrvatska

\begin{abstract}
Sažetak
U ovom radu ispitivan je utjecaj istraživača na rezultate kinetičke analize neizotermne toplinske razgradnje četiri polimera. Analizirani polimeri imaju različite stupnjeve složenosti razgradnog procesa. Kinetičku analizu provelo je troje istraživača, jedan znanstveni savjetnik, jedan znanstveni suradnik te jedan doktorand, a svi su se koristili istim eksperimentalnim termogravimetrijskim podatcima te istim kinetičkim programom (Netzsch Thermokinetics Professional). Rezultati nedvojbeno pokazuju da istraživači imaju značajan utjecaj na rezultate kinetičke analize, budući da su procese neizotermne toplinske razgradnje svih uzoraka opisali različitim kinetičkim shemama i time različitim kinetičkim parametrima.
\end{abstract}

Ključne riječi

Kinetička analiza, neizotermna termogravimetrija, utjecaj istraživača

\section{Uvod}

Prema trenutačno važećim preporukama Međunarodnog udruženja za toplinsku analizu i kalorimetriju, ICTAC (engl. International Confederation for Thermal Analysis and Calorimetry) pod pojmom kinetička analiza podrazumijeva se mjerenje i određivanje parametra brzine kemijskih procesa, a ona se provodi u praktične ili teorijske svrhe. ${ }^{1}$ Pod pojmom polimer podrazumijevaju se sintetske tvari i materijali čiji je osnovni sastojak sustav makromolekula, tj. polimerne makromolekule. ${ }^{2}$

Osnovna praktična svrha kinetičke analize procesa toplinske razgradnje je izračunavanje kinetičkih parametara istraživanog procesa i određivanje njihove ovisnosti o varijablama procesa, temperaturi $(T)$, konverziji $(\alpha)$ i tlaku $(p)$, kako je prikazano u jedn. (1):

$$
\frac{\mathrm{d} \alpha}{\mathrm{d} t}=k(T) \cdot f(\alpha) \cdot h(p)
$$

gdje je $k(T)$ ovisnost o temperaturi, $f(\alpha)$ kinetički model koji opisuje ovisnost o konverziji, a $h(p)$ ovisnost o tlaku. Budući da se ovisnost o temperaturi $k(T)$ kod kinetičke analize procesa toplinske razgradnje u pravilu iskazuje Arrheniusovom ovisnošću, jedn. (1) prelazi u jedn. (2):

$$
\frac{\mathrm{d} \alpha}{\mathrm{d} t}=A \cdot \exp \left(\frac{-E}{R T}\right) \cdot f(\alpha) \cdot h(p)
$$

koja eksplicitno pokazuje kinetičke parametre koje je potrebno izračunati, a to su aktivacijska energija $(E)$, predeksponencijalni faktor $(A)$ i kinetički model $f(\alpha)$. Utvrđivanje njihove ovisnosti o varijablama procesa omogućava predviđanje brzine procesa za bilo koje reakcijske uvjete te

*Autor za dopisivanje: prof. dr. sc. Matko Erceg e-pošta: matko.erceg@ktf-split.hr predviđanje vijeka trajanja materijala pri određenim uvjetima primjene ili preradbe.

Osnovna teorijska svrha kinetičke analize procesa toplinske razgradnje svodi se na objašnjenje izračunatih kinetičkih parametara, čime se postiže bolji uvid u mehanizam istraživanog procesa.

Prema mišljenju autora ovog rada, ne smije se zanemariti ni treći razlog provođenja kinetičke analize procesa toplinske razgradnje, kojemu je osnovna svrha objavljivanje što većeg broja znanstvenih radova u znanstvenim časopisima. Razlog za to je rastući pritisak na znanstvenike/istraživače da objavljuju što više radova budući da broj objavljenih znanstvenih radova postaje sve važnije mjerilo znanstvene uspješnosti i mogućnosti napredovanja u karijeri.

Koja god bila svrha provođenja kinetičke analize procesa toplinske razgradnje, prilikom njezine provedbe potrebno je slijediti preporuke ICTAC-a ${ }^{1}$ da bi dobiveni rezultati bili pouzdani i usporedivi. No često se rezultati kinetičke analize procesa toplinske razgradnje za iste ispitivane materijale znatno razlikuju. Pitanje je zašto - zbog nepridržavanja preporuka ICTAC-a ili za to postoje i drugi razlozi? U ovom radu pokušat će se ukazati na neke moguće uzroke razlika u rezultatima kinetičke analize procesa toplinske razgradnje polimera. Toplinska razgradnja polimera spada u reakcije u čvrstom stanju koje karakterizira razvijanje plinovitih produkata razgradnje. Unatoč toj činjenici, pri provođenju kinetičke analize tih procesa (kao uostalom i kod velike većine istraživanih procesa toplinske razgradnje drugih materijala) zanemaruje se utjecaj tlaka kao varijable procesa, pa jedn. (2) prelazi u jedn. (3) koja se naziva i opća kinetička jednadžba:

$$
\frac{\mathrm{d} \alpha}{\mathrm{d} t}=A \cdot \exp \left(\frac{-E}{R T}\right) \cdot f(\alpha)
$$

gdje je $R$ opća plinska konstanta. U slučaju da se toplinska razgradnja odvija pri konstantnim brzinama zagrijavanja 
$\left(\beta /{ }^{\circ} \mathrm{C} \min ^{-1}\right)$ kao što je slučaj u ovom radu, opća kinetička jednadžba poprima oblik prikazan jedn. (4):

$$
\beta \cdot \frac{\mathrm{d} \alpha}{\mathrm{d} T}=A \cdot \exp \left(\frac{-E}{R T}\right) \cdot f(\alpha)
$$

S matematičkog stajališta, svrha kinetičke analize procesa iniciranih temperaturom jest odrediti matematičku povezanost između brzine procesa, $\mathrm{d} \alpha / \mathrm{d} t$ ili $\beta \mathrm{d} \alpha / \mathrm{d} T$, stupnja konverzije $\alpha$ i temperature, T. ${ }^{1}$ To se određuje izračunavanjem upravo kinetičkih parametara $E, A$ i $f(\alpha)$. Za njihovo izračunavanje razvijene su brojne metode koje se dijele u bezmodelne (engl. model-free) izokonverzijske metode i metode prilagodbe (engl. model-fitting) kinetičkih modela na eksperimentalne podatke. Detaljnije o tim dvama osnovnim pristupima kinetičkoj analizi, ali i mnogo šire, može se pronaći u važećim preporukama ICTAC-a ${ }^{1}$ i knjizi S. Vyazovkina. ${ }^{3}$ Prema preporukama ICTAC-a, kinetičku analizu treba započeti bezmodelnim izokonverzijskim metodama koje omogućavaju određivanje $E$ i njezine ovisnosti o konverziji $(\alpha)$ izravno iz eksperimentalnih podataka, bez pretpostavljanja kinetičkih modela. ${ }^{1}$ Stoga se tako dobivene $E$ vrijednosti smatraju pouzdanim temeljem daljnje provedbe kinetičke analize. Nadalje, ovisnost $E$ o $\alpha$ ukazuje na složenost procesa s kinetičkog stajališta. Ako se $E$ znatno ne mijenja s $\alpha$, proces se karakterizira kao jednostavan i može se opisati jednim kinetičkim stupnjem, odnosno jednim setom kinetičkih parametara $E, A$ i $f(\alpha)$. Ako se $E$ značajno mijenja s $\alpha$, proces se karakterizira kao kinetički složen, a oblik ovisnosti $E$ o $\alpha$ pomaže u određivanju kinetičke sheme ispitivanog procesa. $U$ ovom radu od bezmodelnih izokonverzijskih metoda primijenjena je Friedmanova metoda. ${ }^{4}$ Friedmanova metoda prikazana je jedn. (5):

$$
\ln \left(\frac{\mathrm{d} \alpha}{\mathrm{d} t}\right)_{\alpha}=\ln \left[f(\alpha) \cdot A_{\alpha}\right]-\frac{E_{\alpha}}{R T_{\alpha}} f(\alpha)
$$

Iz ovisnosti $\ln (\mathrm{d} \alpha / \mathrm{d} t)$ o $1 / T$ za svaki odabrani $\alpha=$ konst. iz nagiba pravca izračunava se aktivacijska energija, $E$. Friedmanova metoda je najuniverzalnija izokonverzijska metoda budući da je primjenjiva na različite temperaturne programe. Spada u diferencijalne izokonverzijske metode i za izračunavanje $E$ ne rabi nikakve aproksimacije, već $E$ računa izravno iz eksperimentalnih rezultata.

Od metoda prilagodbe (engl. model-fitting) u ovom radu primijenjena je metoda linearne regresije koja je prikladna za jednostavne, jednostupanjske procese i metoda nelinearne regresije koja je prikladna za složene, višestupanjske procese. Prilagodba se u oba slučaja postiže minimiziranjem razlike između eksperimentalnih i izračunatih podataka, a izračuni su provedeni programom Netzch Thermokinetics Professional. Najboljim kinetičkim modelom smatra se onaj koji daje najmanju razliku između izmjerenih i izračunatih vrijednosti, što se procjenjuje statističkim metodama, primjerice metodom najmanjih kvadrata i $F$-testom. ${ }^{5}$ Statističke metode ne moraju uvijek ispravno ukazivati na kinetički model koji najbolje opisuje stvarni mehanizam procesa budući da statistički jednako prihvatljivi modeli mogu imati znatno različite vrijednosti $E$. Zato se, kao dodatni kriterij, uzima podudaranje $E$ statistički najboljih modela s onima dobivenim izokonverzijskim metodama. Prihvatljiv je onaj kinetički model koji uz zadovoljavanje statističkog kriterija ima i najbolje slaganje aktivacijske energije s vrijednosti energije izračunatom izokonverzijskom metodom. Testirani su svi kinetički modeli programa Netzsch Thermokinetic Professional. ${ }^{6}$

Pregledom rezultata kinetičke analize objavljenih u literaturi za određenu vrstu polimera, mogu se uočiti velike razlike u vrijednostima izračunatih kinetičkih parametara (posebno se uočavaju razlike u kinetičkim shemama i vrijednostima aktivacijske energije). U radu Ercega $i$ sur. $^{7}$ prikazano je nekoliko rezultata kinetičke analize procesa toplinske razgradnje poli(etilen-oksida) (PEO) koji jasno ukazuju na to da su istraživači taj proces opisali potpuno različitim kinetičkim shemama (mehanizmima razgradnje) sa značajno različitim pripadajućim vrijednostima aktivacijske energije. Očito je da se na temelju tih rezultata ne može pouzdano zaključiti o mehanizmu i kinetici procesa toplinske razgradnje PEO-a. Naravno, PEO nije jedini takav primjer u literaturi. Činjenica je da postupak kinetičke analize nije potpuno standardiziran, ${ }^{7}$ već se temelji na preporukama ICTAC-a. Stoga, uzroci razlika u rezultatima kinetičke analize za istu vrstu polimera mogu biti:

a) različiti kinetički pristupi, odnosno primjena različitih metoda kinetičke analize,

b) različita prosječna molekulska masa polimera (polimeri se mogu sintetizirati u vrlo širokom području molekulskih masa),

c) razlika u kvaliteti eksperimentalnih podataka koji se koriste u kinetičkoj analizi i

d) istraživači koji provode kinetičku analizu.

U radu Ercega $i$ sur. ${ }^{7}$ istraživan je utjecaj različitih kinetičkih pristupa odnosno primjene različitih kinetičkih metoda na kinetičke parametre procesa neizotermne toplinske razgradnje PEO-a. U radu su primijenjene bezmodelne izokonverzijske metode (Kissinger-Akahira-Sunose i Friedmanova metoda), metoda nepromjenjivih kinetičkih parametara (IKP), a od metoda prilagodbe (grafička Criadova metoda i Coats-Redfernova metoda) te program Netzch Thermokinetics Professional s uključenom linearnom i nelineranom regresijom. Rezultati su pokazali da su izračunati kinetički parametri $(E, A$ i $f(\alpha))$ ujednačeni bez obzira na primijenjeni kinetički pristup. Štoviše, preporučuje se komplementarna primjena različitih kinetičkih pristupa budući da se tako povećava i stupanj pouzdanosti kinetičke analize.

Utjecaj prosječne molekulske mase PEO-a na rezultate kinetičke analize istraživan je u radu Ercega $i$ sur. ${ }^{8}$ Provedena je kinetička analiza procesa toplinske razgradnje PEO-a u rasponu molekulskih masa od 3400 do 5000 000. Rezultati su pokazali da prosječna molekulska masa utječe na vrijednosti aktivacijske energije (u rasponu od $116,9 \mathrm{~kJ} \mathrm{~mol}^{-1}$ za najnižu molekulsku masu do $201,4 \mathrm{~kJ} \mathrm{~mol}^{-1}$ za najvišu prosječnu molekulsku masu), dok Avrami-Eroffev kinetički model najbolje opisuje toplinsku razgradnju PEO-a svih molekulskih masa. Dakle, ovisno o molekulskoj masi mijenjaju se i parametri kinetičkog modela, ali ne i sam kinetički model. Navedeno ukazuje na to da prosječna molekulska masa PEO-a utječe na brzinu (time i na vrijednost 
aktivacijske energije i parametre kinetičkog modela), ali ne i na mehanizam procesa toplinske razgradnje PEO-a. Stoga, u literaturi uočeni različiti mehanizmi procesa toplinske razgradnje PEO-a ne bi trebali biti posljedica različite molekulske mase ispitivanih polimera.

Jedan od ključnih uvjeta za provedbu pouzdane kinetičke analize je kvaliteta eksperimentalnih podataka. Na kvalitetu eksperimentalnih podataka utječu masa ispitaka, njihov oblik i način pripreme, kalibracija uređaja i istraživač koji provodi mjerenja. Na slikama 1 i 2 prikazani su utjecaji mase, oblika i metode pripreme uzoraka te istraživača) na kvalitetu termogravimetrijskih podataka.

Sva mjerenja su provedena na istom TG uređaju (Pyris 1 TGA). Na slici 1 očit je utjecaj mase, oblika i načina pripreme uzorka na TG podatke. S druge strane, utjecaj istraživača, tj. kalibracije i mjerenja može bit dvojak. Slika $2 a$ pokazuje vrlo dobro, a slika 2 b slabije podudaranje TG mjerenja koje su provela dva različita istraživača ( $\mathrm{A}$ i B) na istom uzorku i istom TG uređaju te pri potpuno istim uvjetima mjerenja. Razlika na slici $2 b$ može se pripisati jedino istraživaču koji je proveo kalibraciju i mjerenje, budući da su svi ostali faktori koji utječu na TG mjerenje identični. Na slici 2 b prikazan je i utjecaj tako dobivenih TG podataka na iz njih izračunatu $E$ Friedmanovom izokonverzijskom metodom. Razlika iznosi oko $5 \mathrm{~kJ} \mathrm{~mol}^{-1}$.

Iz rezultata prikazanih na slikama 1 i 2 može se potvrditi da kvaliteta eksperimentalnih podataka ima utjecaja na rezultate kinetičke analize, a da na kvalitetu TG podataka utječu masa, oblik i način pripreme uzorka te sami istraživači prilikom kalibracije i provedbe TG mjerenja. Samim time, navedeno ima utjecaj i na rezultate kinetičke analize koji će se zasigurno razlikovati zbog razlike u kvaliteti TG podataka. Utjecaj mase, oblika i načina pripreme uzorka mogu se dobrom laboratorijskom praksom gotovo potpuno eliminirati, dok utjecaj istraživača ostaje zabrinjavajući čimbenik pouzdanosti.

Kako bi se eliminirao utjecaj kvalitete TG podataka na rezultate kinetičke analize $\mathrm{i}$ ispitao utjecaj istraživača na rezultate kinetičke analize tijekom provedbe samih izračuna, u ovom radu su identični eksperimentalni TG podatci podijeljeni trima istraživačima Zavoda za organsku tehnologiju Kemijsko-tehnološkog fakulteta u Splitu. Jedan
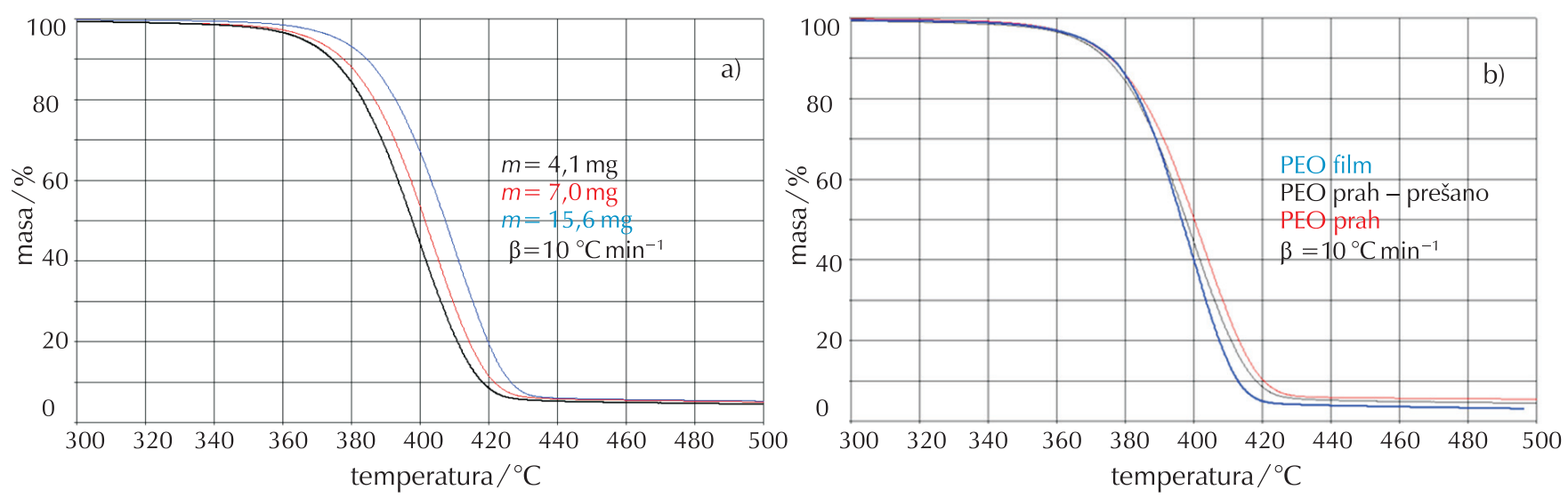

Slika 1 - Utjecaj a) mase uzorka i b) oblika i pripreme uzorka na TG krivulje PEO-a

Fig. 1 - Influence of a) sample mass, and b) shape and preparation of sample on TG curves of PEO
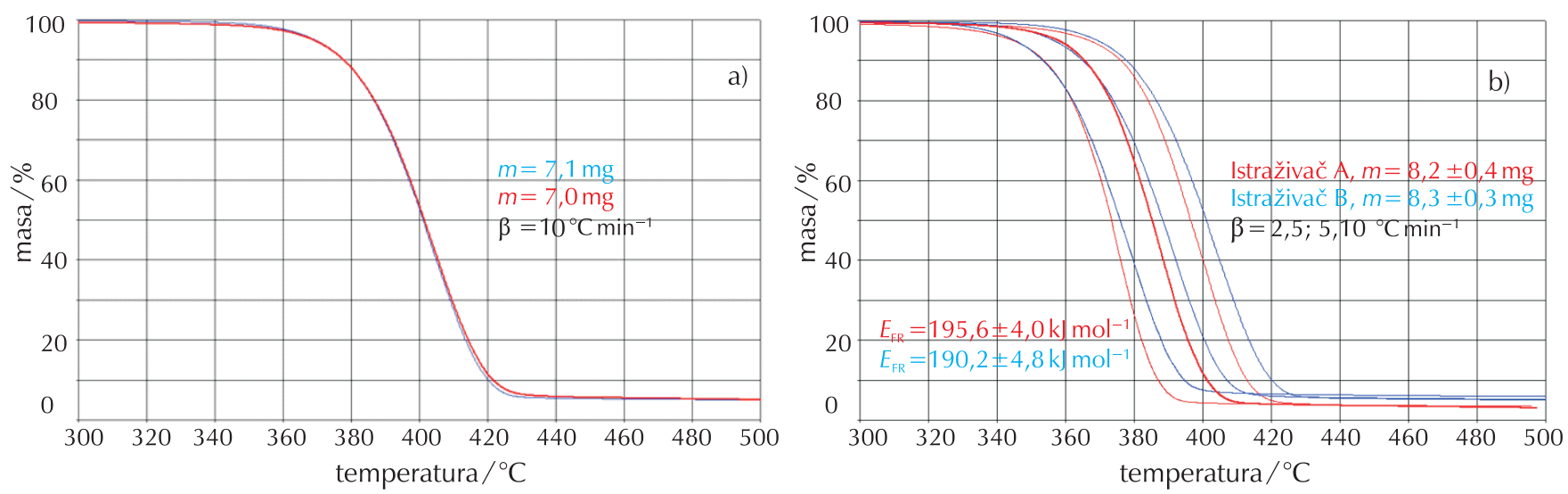

Slika 2 - Utjecaj istraživača: a) dobro podudaranje TG mjerenja; b) loše podudaranje TG mjerenja i utjecaj na Friedmanovu aktivacijsku energiju

Fig. 2 - Influence of investigator: a) good matching of TG measurements; b) poor matching of TG measurements and influence on Friedman activation energy 
istraživač je u zvanju znanstvenog savjetnika (I1), drugi je znanstveni suradnik (I2), a treći je doktorand (I3). Zadatak je provesti kinetičku analizu primjenom programa Netzsch Thermokinetics Professional i usporediti dobivene rezultate. Cilj rada je istražiti koliko sami istraživači koji provode kinetičku analizu utječu na rezultate kinetičke analize.

\section{Eksperimentalni dio}

\subsection{Materijal}

U radu su upotrijebljeni sljedeći materijali:

- prah poli(etilen-oksida) (PEO) viskoznog prosjeka molekulske mase $M_{\mathrm{v}}=300000 \mathrm{~g} \mathrm{~mol}^{-1}$, proizvođača Dow Chemical,

- prah poli(3-hidroksibutirata) (PHB) viskoznog prosjeka molekulskih masa $M_{v}=350000 \mathrm{~g} \mathrm{~mol}^{-1}$, proizvođača Biomer,

- nanokompozit PEO $\left(M_{v}=300000 \mathrm{~g} \mathrm{~mol}^{-1}\right)$ i litijeva montmorilonita (LiMMT) sastava 90 mas.\% PEO i 10 mas.\% LiMMT (PEO/LiMMT 90/10),

- prah poli(vinil-klorida) (PVC) viskoznog prosjeka molekulske mase $M_{v}=86000 \mathrm{~g} \mathrm{~mol}^{-1}$, proizvođača Solvin.

\subsection{Priprema uzoraka}

Prahovi poli(etilen-oksida) (PEO), poli(3-hidroksibutirata) (PHB) i poli(vinil-klorida) (PVC) prešani su u tabletice promjera $13 \mathrm{~mm}$ i debljine oko $0,8 \mathrm{~mm}$ na hidrauličkoj preši Specac (pritisak $50 \mathrm{~N} \mathrm{~mm}^{-2}$ ) upotrebljavajući kalup za pripremu uzoraka tehnikom $\mathrm{KBr}$.

Prahovi PEO-a i litijeva montmorilonita (LiMMT) u masenom omjeru 90 mas.\% PEO i 10 mas.\% LiMMT (PEO/ LiMMT 90/10) ručno su miješani u ahatnom tarioniku $10 \mathrm{~min}$ i prešani u tabletice promjera $13 \mathrm{~mm}$ i debljine oko 0,8 mm na hidrauličkoj preši Specac upotrebljavajući kalup za pripremu uzoraka tehnikom KBr. Nanokompozit je pripremljen interkalacijom iz taljevine pri $90{ }^{\circ} \mathrm{C}$ tijekom 8 h u vakuumskom sušioniku. ${ }^{9}$

\subsection{Neizotermna termogravimetrijska razgradnja}

Neizotermna TG razgradnja PHB, PVC i PEO/LiMMT 90/10 uzoraka provedena je pri brzinama zagrijavanja $2,5{ }^{\circ} \mathrm{Cmin}^{-1}, 5^{\circ} \mathrm{C} \mathrm{min}^{-1}, 10{ }^{\circ} \mathrm{C} \mathrm{min}^{-1}$ i $20^{\circ} \mathrm{Cmin}^{-1} \mathrm{u}$ temperaturnom području $50-650{ }^{\circ} \mathrm{C}$ (PVC) te $50-500{ }^{\circ} \mathrm{C}$ (PHB i PEO/LiMMT 90/10). PEO je razgrađivan pri brzinama zagrijavanja $2,5{ }^{\circ} \mathrm{C} \mathrm{min}^{-1}, 5{ }^{\circ} \mathrm{C} \mathrm{min}^{-1}, 10{ }^{\circ} \mathrm{C} \mathrm{min}^{-1}$ u temperaturnom području $50-500{ }^{\circ} \mathrm{C}$. Mjerenja su provedena u struji dušika $\left(30 \mathrm{~cm}^{3} \mathrm{~min}^{-1}\right)$ na TG uređaju Perkin-Elmer Pyris 1 TGA. Masa svih uzoraka bila je u području $10 \pm 1 \mathrm{mg}$

\subsection{Kinetička analiza}

Kinetička analiza toplinske razgradnje polimera provedena je primjenom programa Netzsch Thermokinetics Professional sukladno postupcima opisanim u Uvodu i preporukama ICTAC-a. Analiza je provedena u cijelom konverzijskom području ( $\alpha=0,005-0,995)$. U prvom koraku, primjenom Friedmanove metode izračunata je aktivacijska energija i njezina ovisnost o konverziji. Iz te ovisnosti izveden je zaključak o složenosti procesa. Kod onih uzoraka kod kojih nema značajnije promjene aktivacijske energije s konverzijom zaključeno je da se radi o kinetički jednostavnom, jednostupanjskom procesu te je primijenjena linearna regresijska metoda. Kod onih uzoraka kod kojih postoji značajnija promjena aktivacijske energije s konverzijom zaključeno je da se radi o kinetički složenom, višestupanjskom procesu te je primijenjena nelinearna regresijska metoda s ciljem definiranja najvjerojatnije kinetičke sheme i kinetičkih parametara svakog pojedinog stupnja. Kao kriteriji primijenjeni su statistički F-test i usporedba dobivenih vrijednosti aktivacijske energije statistički najvjerojatnijih kinetičkih modela s vrijednostima dobivenim Friedmanovom izokonverzijskom metodom. Na temelju rezultata izveden je zaključak o utjecaju istraživača koji provode kinetičku analizu na rezultate kinetičke analize.

\section{Rezultati i rasprava}

Uzroci razlika u rezultatima kinetičke analize za istu vrstu polimera mogu biti različiti kinetički pristupi, različita prosječna molekulska masa polimera, razlika u kvaliteti eksperimentalnih podataka i u istraživačima koji provode kinetičku analizu. Troje istraživača provelo je kinetičku analizu istih eksperimentalnih podataka primjenom istog računalnog programa. Stoga bi eventualne razlike u konačnim rezultatima kinetičke analize trebale biti posljedica utjecaja samih istraživača.

Termogravimetrijske (TG) i derivativne termogravimetrijske (DTG) krivulje za poli(etilen-oksid) (PEO), poli(3-hidroksibutirat) $(\mathrm{PHB})$, nanokompozit $\mathrm{PEO}$ i litijeva montmorilonita (LiMMT) (PEO/LiMMT 90/10) te poli(vinil-klorid) (PVC) prikazane su na slici 3.

Friedmanova izokonverzijska analiza prvi je korak u metodologiji provedbe kinetičke analize primjenom programa Netzsch Thermokinetics Professional. ${ }^{6}$ Metoda omogućava izračun aktivacijske energije $(E)$ i njezine ovisnosti o konverziji $(\alpha)$ izravno iz eksperimentalnih podataka. Budući da se upotrebljavaju isti eksperimentalni podatci i isti računalni program rezultati bezmodelne izokonverzijske Fridmanove metode identični su kod svih troje istraživača. Ovisnost aktivacijske energije o konverziji prikazana je na slici 4, dok su Fridmanovi grafovi prikazani na slici 5.

Analizom TG i DTG krivulja na slici 3, ovisnosti aktivacijske energije o konverziji na slici 4 te Friedmanovih grafova na slici 5 može se zaključiti o složenosti procesa toplinske razgradnje svakog uzorka. Razmatrano je cijelo konverzijsko područje za sve uzorke. Kinetičke sheme troje istraživača međusobno su uspoređene te je na temelju F-testa zaključeno koja je shema statistički najvjerojatnija. Podudaranje 

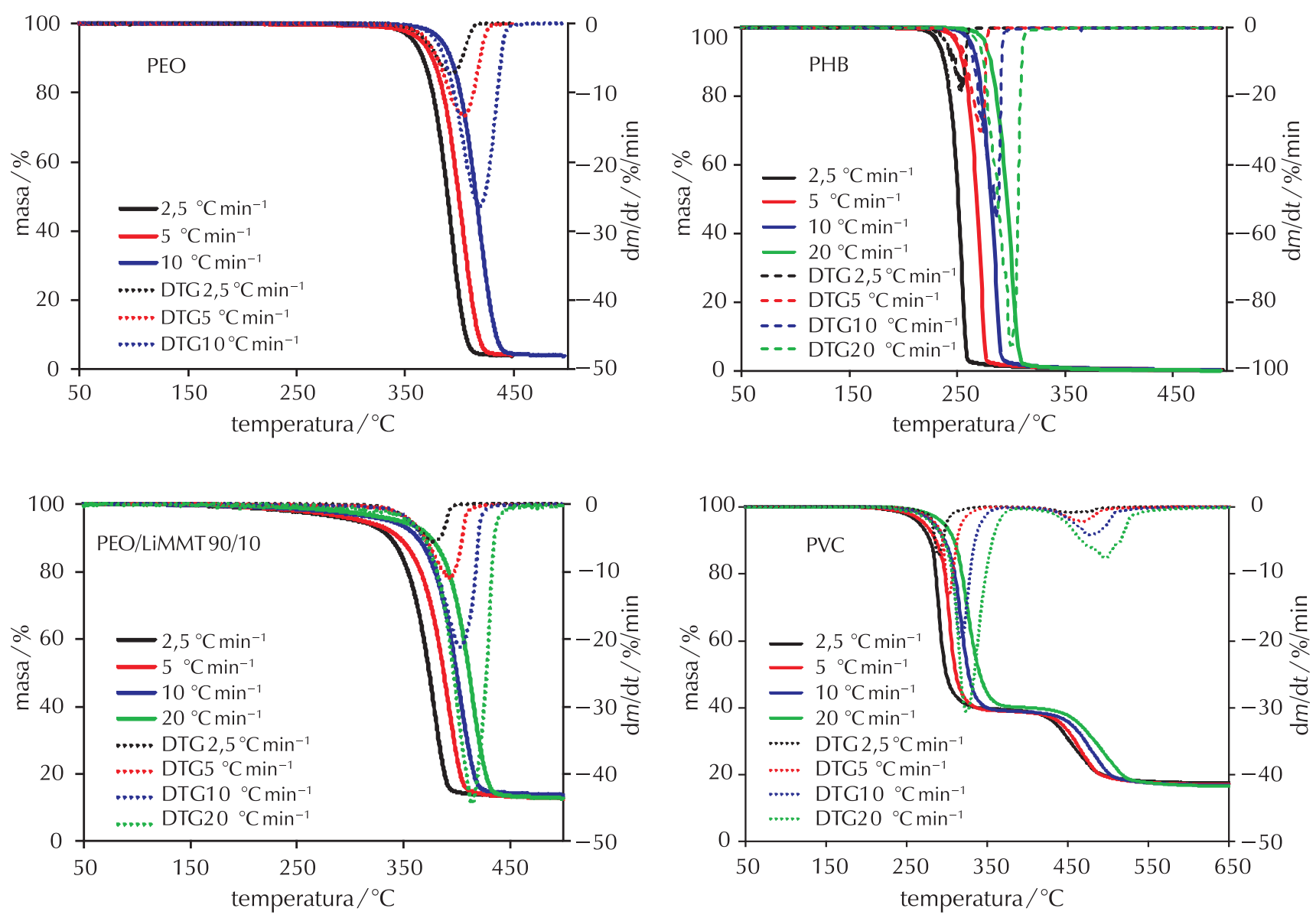

Slika 3 - TG i DTG krivulje za PEO, PHB, PEO/LiMMT 90/10 i PVC pri različitim brzinama zagrijavanja Fig. 3 - TG and DTG curves for PEO, PHB, PEO/LiMMT 90/10, and PVC at different heating rates

izračunatih podataka s eksperimentalnim izračunava se prema jedn. (6):

$$
S_{j}^{2}=\frac{1}{n-1} \sum_{i=1}^{n}\left((\mathrm{~d} \alpha / \mathrm{d} t)_{\exp }-(\mathrm{d} \alpha / \mathrm{d} t)_{\operatorname{model}}\right)^{2}
$$

gdje je $S^{2}$, varijanca, $n$ broj mjernih točaka, $(\mathrm{d} \alpha / \mathrm{d} t)_{\exp }$ eksperimentalne, a $(\mathrm{d} \alpha / \mathrm{d} t)_{\text {model }}$ izračunate vrijednosti za pojedini kinetički model. Dijeljenjem $S^{2}$ svakog pojedinog kinetičkog modela s minimalnom vrijednosti varijance svih promatranih modela $S_{\text {min, }}^{2}$ dobivene su vrijednosti $F_{\exp }(7)$ :

$$
F_{\exp }=\frac{S_{j}^{2}}{S_{\text {min }}^{2}} \leq F_{\text {krit }}
$$

Prema $F$-testu, samo oni kinetički modeli za koje vrijedi $F_{\text {exp }}<F_{\text {krit. }}$ Smatraju se statistički vjerojatnim za opis procesa promatranog procesa.

\subsection{Poli(etilen-oksid) (PEO)}

PEO se razgrađuje $u$ jednom stupnju statističkim cijepanjem polimernih lanaca bez depolimerizacije, ${ }^{7,9}$ na što ukazuju TG i DTG krivulje (jedan stupanj razgradnje - jedan pik na DTG krivulji), jednostavna ovisnost $E$ o $\alpha$ (kon-

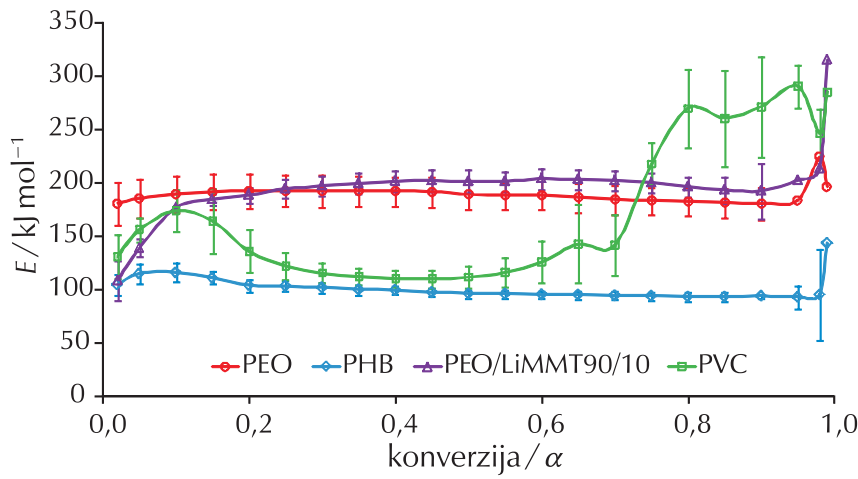

Slika 4 - Ovisnost aktivacijske energije $(E)$ o konverziji $(\alpha)$ za PEO, PHB, PEO/LiMMT 90/10 i PVC

Fig. 4 -Dependence of activation energy $(E)$ on conversion $(\alpha)$ for PEO, PHB, PEO/LiMMT 90/10, and PVC

stantna vrijednost $E$ u cijelom konverzijskom području) i samo jedan pik na Friedmanovu grafu. Iz Friedmanova grafa također je vidljivo da eksperimentalni podatci na početku reakcije $(\alpha=0,02-0,10)$ imaju veći nagib od Friedmanovih izokonverzijskih pravaca, što ukazuje na autokatalitičke i Avrami-Erofeeve kinetičke modele. Istraživači I1 i I3 zaključili su da se radi o jednostavnom, jednostupanj- 

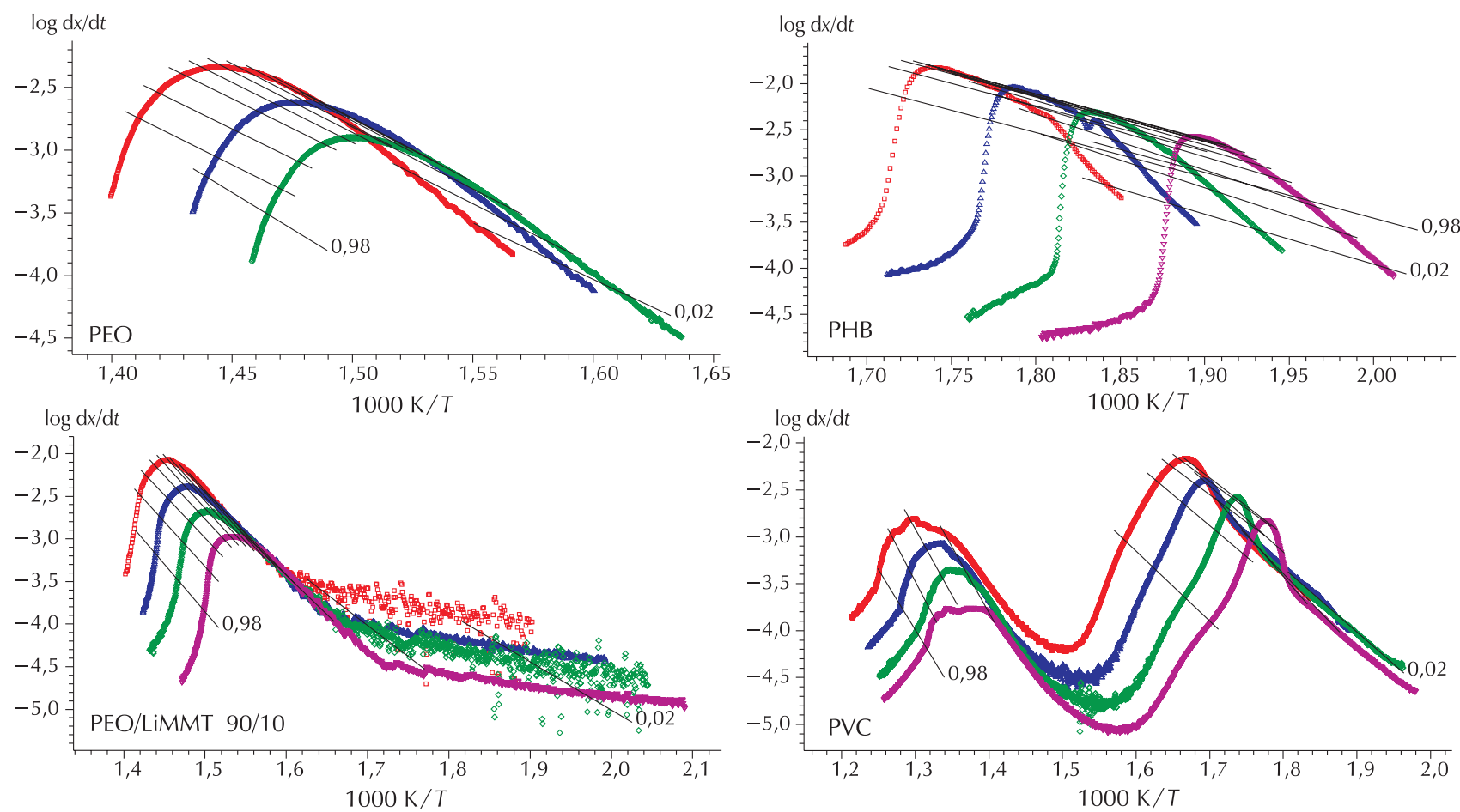

Slika 5 - Friedmanovi grafovi za PEO, PHB, PEO/LiMMT 90/10 i PVC

Fig. 5 - Friedman's graphs for PEO, PHB, PEO/LiMMT 90/10, and PVC

skom procesu koji se najbolje može opisati Avrami-Erofeevim (An) kinetičkim modelom te su do konačnih rezultata došli primjenom linearne regresije. Istraživač I2 zaključio je da se radi o složenom procesu koji se sastoji od tri stupnja razgradnje i proces opisuje Avrami-Erofeevim (An) modelom, koji prati prošireni Prout-Tompkinsov (Bna) model i konačno slijedi model $n$-tog reda (Fn) za što je primijenio nelinearnu regresiju. Na temelju činjenice da ostatna masa ne ovisi o brzini zagrijavanja, istraživač I2 zaključio je da se radi o slijednim reakcijama bez reakcija grananja. Rezultati kinetičke analize svih istraživača prikazani su u tablici 1 . Kinetičke sheme su zatim uspoređene da bi se utvrdilo koja je statistički vjerojatnija. Obje zadovoljavaju $F$-test i obje se mogu smatrati statistički vjerojatnima. Nešto bolje podudaranje izračunatih podataka s eksperimentalnim je primijećeno kod istraživača I2 u odnosu na shemu I1 i I3 $\left(r^{2}=0,999547\right.$ u odnosu na $\left.r^{2}=0,999532\right)$.

Slaganje aktivacijske energije za dobivene modele s onom dobivenom Friedmanovom izokonverzijskom metodom $\left(E_{\mathrm{FR}}\right)$ dobro je za obje kinetičke sheme, uzimajući u obzir konverzijska područja u kojima se kinetička shema primjenjuje. Na temelju navedenog i preporuke ICTAC-a da je novi stupanj u kinetičkoj analizi potrebno uvoditi samo ako dovodi do značajnog poboljšanja prilagodbe izračunatih podataka eksperimentalnim, ${ }^{1}$ zaključuje se da je toplinska razgradnja PEO-a jednostupanjski proces koji se opisuje Avrami-Erofeevim (An) kinetičkim modelom, odnosno ki-

Tablica 1 - Rezultati kinetičke analize za PEO

Table 1 - Results of the kinetic analysis for PEO

\begin{tabular}{|c|c|c|c|c|c|}
\hline $\begin{array}{l}\text { Istraživač } \\
\text { Researcher }\end{array}$ & 11 & \multicolumn{3}{|c|}{12} & 13 \\
\hline $\begin{array}{l}\text { Kinetička shema } \\
\text { Kinetic scheme }\end{array}$ & An & An & Bna & $\mathrm{Fn}$ & An \\
\hline$E / \mathrm{kJ} \mathrm{mol}^{-1}$ & 187 & 187 & 182 & 224 & 187 \\
\hline $\log \mathrm{A} / \mathrm{s}^{-1}$ & 12,06 & 14,49 & 11,97 & 15,11 & 12,06 \\
\hline $\begin{array}{l}\text { parametri modela } \\
\text { model parameters }\end{array}$ & $n=1,50$ & $n=1,50$ & $\begin{array}{l}n=0,78 \\
a=0,35\end{array}$ & $n=0,84$ & $n=1,50$ \\
\hline $\begin{array}{l}\text { konverzijsko područje modela } \\
\text { model conversion range }\end{array}$ & 1,000 & 0,005 & 0,487 & 0,508 & 1,000 \\
\hline$F_{\text {exp }}\left(F_{\text {krit. }}=1,03\right)$ & 1,03 & \multicolumn{3}{|c|}{1,00} & 1,03 \\
\hline$r^{2}$ & 0,999532 & \multicolumn{3}{|c|}{0,999547} & 0,999532 \\
\hline
\end{tabular}


Tablica 2 - Rezultati kinetičke analize za PHB

Table 2 - Results of the kinetic analysis for PHB

\begin{tabular}{|c|c|c|c|c|c|c|c|}
\hline $\begin{array}{l}\text { Istraživač } \\
\text { Researcher }\end{array}$ & \multicolumn{2}{|c|}{ I1 } & \multicolumn{3}{|c|}{12} & \multicolumn{2}{|c|}{13} \\
\hline $\begin{array}{l}\text { Kinetička shema } \\
\text { Kinetic scheme }\end{array}$ & An & $\mathrm{Fn}$ & A3 & $\mathrm{CnC}$ & F2 & $\mathrm{CnB}$ & An \\
\hline$E / \mathrm{kJ} \mathrm{mol}^{-1}$ & 104 & 139 & 106 & 100 & 142 & 103 & 98 \\
\hline $\log A / s^{-1}$ & 7,60 & 11,71 & 7,89 & 7,02 & 10,08 & 6,24 & 9,14 \\
\hline $\begin{array}{l}\text { parametri modela } \\
\text { model parameters }\end{array}$ & $n=3,36$ & $n=3,91$ & - & $\begin{array}{c}n=0,65 \\
\operatorname{logKcat}=0,8\end{array}$ & - & $\begin{array}{l}n=0,00018 \\
\operatorname{logKcat}=2\end{array}$ & $n=0,30$ \\
\hline $\begin{array}{l}\text { konverzijsko područje modela } \\
\text { model conversion range }\end{array}$ & 0,966 & 0,034 & 0,378 & 0,604 & 0,018 & 0,301 & 0,699 \\
\hline$F_{\text {exp }}\left(F_{\text {krit. }}=1,03\right)$ & \multicolumn{2}{|c|}{1,03} & \multicolumn{3}{|c|}{1,00} & \multicolumn{2}{|c|}{1,01} \\
\hline$r^{2}$ & \multicolumn{2}{|c|}{0,999402} & \multicolumn{3}{|c|}{0,999415} & \multicolumn{2}{|c|}{0,999415} \\
\hline
\end{tabular}

netičkim shemama istraživača I1 i I3 (slika 6). Navedeno je u skladu s već objavljenim rezultatima kinetičke analize PEO-a. 7,15

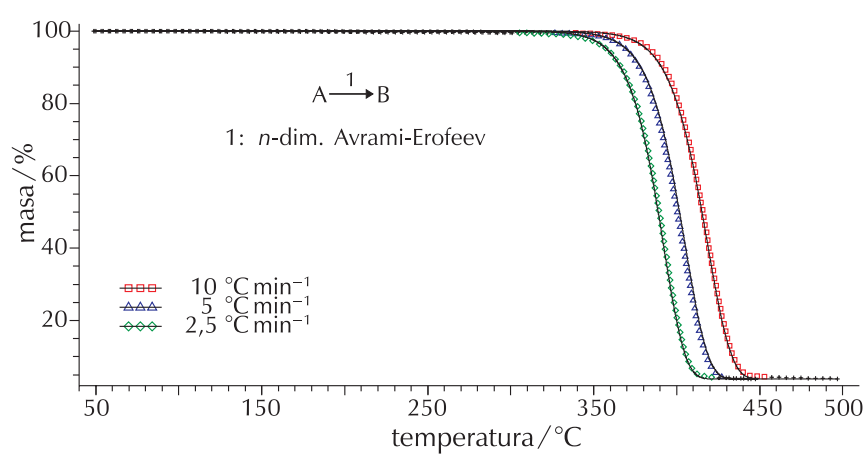

Slika 6 - Usporedba eksperimentalnih i izračunatih TG krivulja za PEO

Fig. 6 -Comparison of the experimental and calculated TG curves for PEO

\subsection{Poli(3-hidroksibutirat) (PHB)}

Osnovni mehanizam toplinske razgradnje PHB-a je statističko cijepanje njegovih polimernih lanaca, a proces karakterizira iznimno velika brzina razgradnje. ${ }^{10,11} \mathrm{U}$ radu Ercega $i$ sur. ${ }^{12}$ je primjenom izokonverzijskih metoda, metode nepromjenjivih kinetičkih parametara (IKP) ${ }^{13}$ i kriterija Pérez-Maquede $i$ sur. ${ }^{14}$ zaključeno da se PHB u konverzijskom području $\alpha=0,10-0,90$ razgrađuje u jednom stupnju i da proces najbolje opisuje Avrami-Erofeev kinetički model (An). Analizom TG i DTG krivulja, ovisnosti E o $\alpha$ i Friedmanova grafa, svi istraživači su zaključili da se radi o složenoj kinetičkoj shemi (razmatrano je cijelo konverzijsko područje). Iz Friedmanova grafa također je vidljivo da eksperimentalni podatci na početku reakcije $(\alpha=0,02-0,10)$ imaju veći nagib od Friedmanovih izokonverzijskih pravaca, što ukazuje na autokatalitičke i/ili Avrami-Erofeeve kinetičke modele. Istraživači I1 i I3 zaključili su da se radi o dvostupanjskom procesu, dok je istraživač I2 zaključio da se radi o trostupanjskom procesu. Istraživač I1 je proces opisao An i Fn kinetičkim modelima, istraživač 13 reakcijom $n$-tog reda s autokatalizom $(\mathrm{CnB}) \mathrm{i}$ An modelom, dok je istraživač 12 proces opisao $\mathrm{A} 3, \mathrm{CnC}$ i reakcijom drugog reda (F2). Na temelju činjenice da ostatna masa ne ovisi o brzini zagrijavanja, svi su zaključili da se radi o slijednim reakcijama te da nema reakcija grananja. Kinetičke sheme zatim su uspoređene da bi se utvrdilo koja je statistički vjerojatnija. Usporedba pokazuje da sve tri kinetičke sheme zadovoljavaju statistički F-test i sve se mogu smatrati statistički vjerojatnima. Najbolje podudaranje izračunatih podataka s eksperimentalnim je primijećeno kod istraživača I2 (slika 7), zatim I3 te I1. Rezultati su prikazani u tablici 2.

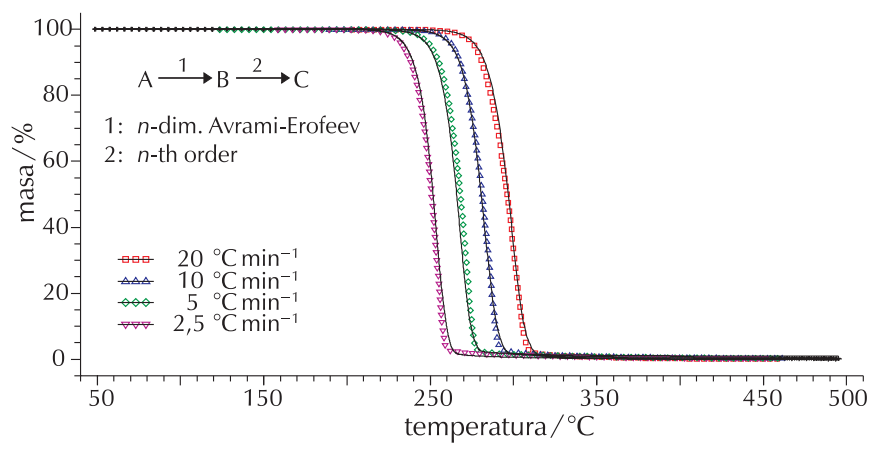

Slika 7 - Usporedba eksperimentalnih i izračunatih TG krivulja za PHB

Fig. 7 -Comparison of the experimental and calculated TG curves for $\mathrm{PHB}$

Slaganje aktivacijske energije za dobivene modele s onima dobivenim Friedmanovom izokonverzijskom metodom $\left(E_{\mathrm{FR}}\right)$ dobro je za sve kinetičke sheme, uzimajući u obzir konverzijska područja u kojima se kinetička shema primjenjuje. Na temelju navedenog i preporuke ICTAC-a da je novi stupanj u kinetičkoj analizi potrebno uvoditi samo ako dovodi do značajnog poboljšanja prilagodbe izračunatih 
podataka eksperimentalnim, ${ }^{1}$ zaključuje se da je toplinska razgradnja PHB-a dvostupanjski proces. Između kinetičkih shema An - Fn i CnB - An preporučuje se izabrati kinetičku shemu An - Fn (slika 9) zbog toga što An kinetički model bolje mehanistički opisuje proces toplinske razgradnje PHB-a. Nadalje, An kinetički model vrijedi u konverzijskom području 0,005 - 0,966 (praktično cijelo konverzijsko područje) pa je i tu nađeno dobro podudaranje s rezultatima Ercega i sur., gdje u konverzijskom području $\alpha=0,10-0,90$ proces najbolje opisuje Avrami-Erofeev kinetički model (An). ${ }^{12}$

\subsection{Poli(etilen-oksid)/litijev montmorilonit (PHB/LiMMT 90/10)}

Kinetička analiza procesa neizotermne toplinske razgradnje nanokompozita PEO/LiMMT istraživana je u radu Ercega i sur., ${ }^{15}$ a među njima i PEO/LiMMT 90/10. Analizom TG i DTG krivulja, ovisnosti $E$ o $\alpha$ i Friedmanova grafa, svi istraživači su zaključili da se radi o složenoj kinetičkoj shemi. Iz Friedmanova grafa vidljivo je da eksperimentalni podatci na početku reakcije $(\alpha=0,02-0,10)$ imaju manji nagib od Friedmanovih izokonverzijskih pravaca, što ukazuje na difuzijske (D) kinetičke modele na početku reakcije. Istraživač I1 proces je opisao četverostupanjskom kinetičkom shemom koja sadrži difuzijski (D3) model, Fn, An i konačno Fn kinetički model. Istraživač 12 je proces također opisao četverostupanjskom shemom koja sadrži D3, An, An i Fn kinetičke modele, dok je istraživač I3 opisao proces trostupanjskom shemom koja sadrži D3, CnC i Fn kinetičke modele. Na temelju činjenice da ostatna masa ne ovisi o brzini zagrijavanja, svi su zaključili da se radi o slijednim reakcijama. Slaganje aktivacijske energije za dobivene modele s onima dobivenim Friedmanovom izokonverzijskom metodom $\left(E_{\mathrm{FR}}\right)$ dobro je za sve kinetičke sheme, uzimajući u obzir konverzijska područja u kojima se kinetička shema primjenjuje. Kinetičke sheme zatim su uspoređene da bi se utvrdilo koja je statistički vjerojatnija. U ovom slučaju, nakon međusobne usporedbe, samo ki- netička shema istraživača 11 zadovoljava statistički F-test, te se stoga zaključuje se da je toplinska razgradnja PEO/ LiMMT 90/10 višestupanjski proces koji se najbolje opisuje D3 - Fn - An - Fn kinetičkom shemom (slika 8). Rezultati su prikazani u tablici 3 .

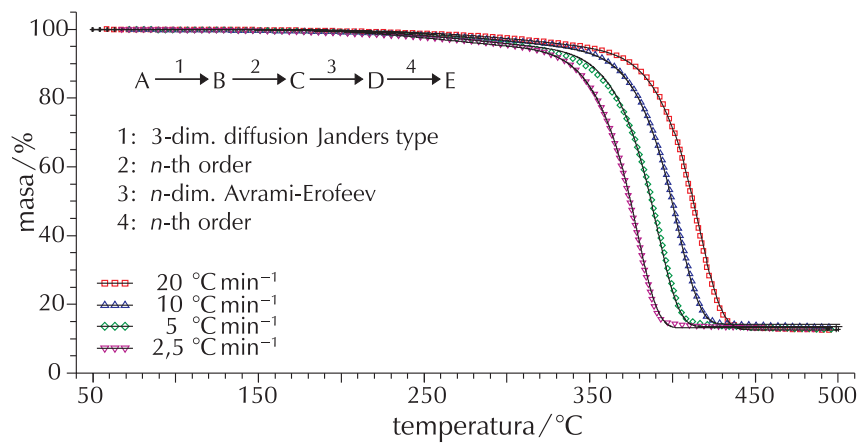

Slika 8 - Usporedba eksperimentalnih i izračunatih TG krivulja za PEO/LiMMT 90/10

Fig. 8 -Comparison of the experimental and calculated TG curves for PEO/LiMMT 90/10

\subsection{Poli(vinil-klorid) (PVC)}

Mehanizam razgradnje PVC-a proveden u dušiku odvija se kroz dva temeljna stupnja: prvi je dehidrokloriranje, a drugi piroliza karboniziranog ostatka. ${ }^{16}$ Analizom TG i DTG krivulja, ovisnosti $E$ o $\alpha$ i Friedmanova grafa, svi istraživači su zaključili da se radi o složenoj kinetičkoj shemi. Također, svi su zaključili da su reakcije slijedne budući da ostatna masa ne ovisi o brzini zagrijavanja u oba temeljna stupnja. Općenito, toplinska razgradnja PVC-a odvija se kroz dva temeljna stupnja razgradnje, pri čemu prvi temeljni stupanj odgovara reakciji dehidrokloriranja uz nastanak konjugirane polienske strukture. $U$ drugom temeljnom

Tablica 3 - Rezultati kinetičke analize za PEO/LiMMT 90/10

Table 3 - Results of the kinetic analysis for PEO/LiMMT 90/10

\begin{tabular}{|c|c|c|c|c|c|c|c|c|c|c|c|}
\hline $\begin{array}{l}\text { Istraživač } \\
\text { Researcher }\end{array}$ & \multicolumn{4}{|c|}{11} & \multicolumn{4}{|c|}{12} & \multicolumn{3}{|c|}{13} \\
\hline $\begin{array}{l}\text { Kinetička shema } \\
\text { Kinetic scheme }\end{array}$ & D3 & Fn & An & Fn & D3 & An & An & Fn & D3 & $\mathrm{CnC}$ & $\mathrm{Fn}$ \\
\hline$E / \mathrm{kJ} \mathrm{mol}^{-1}$ & 105 & 168 & 202 & 202 & 103 & 170 & 202 & 245 & 103 & 199 & 210 \\
\hline $\log A / s^{-1}$ & 6,51 & 11,34 & 13,54 & 27,22 & 6,39 & 13,60 & 13,60 & 17,81 & 6,35 & 13,23 & 15,03 \\
\hline $\begin{array}{l}\text { parametri modela } \\
\text { model parameters }\end{array}$ & - & $n=0,80$ & $n=1,43$ & $n=3,70$ & - & $n=1,05$ & $n=1,54$ & $n=3,21$ & - & $\begin{array}{c}n=0,74 \\
\log \text { Kcat }=-0,2\end{array}$ & $n=4,08$ \\
\hline $\begin{array}{c}\text { konverzijsko područje } \\
\text { modela } \\
\text { model conversion } \\
\text { range }\end{array}$ & 0,052 & 0,156 & 0,380 & 0,412 & 0,051 & 0,161 & 0,711 & 0,077 & 0,051 & 0,901 & 0,048 \\
\hline$F_{\text {exp }}\left(F_{\text {krit. }}=1,03\right)$ & \multicolumn{4}{|c|}{1,00} & \multicolumn{4}{|c|}{1,32} & \multicolumn{3}{|c|}{2,49} \\
\hline$r^{2}$ & \multicolumn{4}{|c|}{0,999922} & \multicolumn{4}{|c|}{0,999901} & \multicolumn{3}{|c|}{0,999823} \\
\hline
\end{tabular}


Tablica 4 - Rezultati kinetičke analize za PVC

Table 4 - Results of the kinetic analysis for PVC

\begin{tabular}{|c|c|c|c|c|c|c|c|c|c|c|c|c|}
\hline \multirow{2}{*}{$\begin{array}{c}\text { Istraživač } \\
\text { Researcher } \\
\begin{array}{l}\text { Kinetička shema } \\
\text { Kinetic scheme }\end{array}\end{array}$} & \multicolumn{4}{|c|}{11} & \multicolumn{5}{|c|}{12} & \multicolumn{3}{|c|}{13} \\
\hline & D3 & $\mathrm{CnC}$ & An & $\mathrm{Fn}$ & D4 & $\mathrm{CnC}$ & $\mathrm{CnD}$ & An & Fn & Fn & Bna & Fn \\
\hline$E / \mathrm{kJ} \mathrm{mol}^{-1}$ & 172 & 126 & 150 & 278 & 130 & 172 & 122 & 139 & 289 & 156 & 137 & 283 \\
\hline $\log \mathrm{A} / \mathrm{s}^{-1}$ & 12,65 & 8,69 & 12,07 & 17,39 & 8,73 & 13,40 & 8,45 & 9,94 & 18,15 & 11,78 & 10,78 & 17,75 \\
\hline $\begin{array}{l}\text { parametri } \\
\text { modela } \\
\text { model } \\
\text { parameters }\end{array}$ & - & $\begin{array}{c}n=0,94 \\
\text { logKcat }=1,0\end{array}$ & $n=0,29$ & $n=1,93$ & - & $\begin{array}{c}n=0,31 \\
\text { logKcat }=-0,3\end{array}$ & $\begin{array}{c}n=1,52 \\
\operatorname{logKcat}=1,1\end{array}$ & $n=1,66$ & $n=2,00$ & - & $n=2,0$ & $n=1,97$ \\
\hline $\begin{array}{c}\text { konverzijsko } \\
\text { područje modela } \\
\text { model } \\
\text { conversion range }\end{array}$ & 0,101 & 0,388 & 0,247 & 0,412 & 0,058 & 0,188 & 0,401 & 0,092 & 0,261 & 0,345 & 0,599 & 0,056 \\
\hline$F_{\text {exp }}\left(F_{\text {krit. }}=1,02\right)$ & \multicolumn{4}{|c|}{1,45} & \multicolumn{5}{|c|}{1,00} & \multicolumn{3}{|c|}{1,28} \\
\hline$r^{2}$ & \multicolumn{4}{|c|}{0,999911} & \multicolumn{5}{|c|}{0,999938} & \multicolumn{3}{|c|}{0,999928} \\
\hline
\end{tabular}

stupnju uslijed intermolekulske ciklizacije polienski spojevi iznad $360{ }^{\circ} \mathrm{C}$ podliježu aromatizaciji što dovodi do nastanka hlapljivih aromata (benzen, naftalen) ili pak uslijed reakcije intermolekulskog umrežavanja do nastanka alkil aromata i čađe iznad $500{ }^{\circ} \mathrm{C}$. Iz Friedmanova grafa vidljivo je da eksperimentalni podatci na početku reakcije $(\alpha=0,02-0,10)$ imaju identičan nagib kao i Friedmanovi izokonverzijski pravci, što ukazuje na Fn ili R2 i R3 (reakcija na granici faza) kinetičke modele na početku reakcije. Istraživač I1 je taj proces opisao kroz pet elementarnih stupnjeva, D3, CnC i An te An i Fn. Istraživač I2 je taj proces opisao također kroz pet elementarnih stupnjeva, D4, dva Cn stupnja značajno različite aktivacijske energije te An i Fn. Istraživač I3 je proces opisao u tri stupnja Fn, Bna i Fn. Svi istraživači su na temelju činjenice da ostatna masa u oba temeljna stupnja ne ovisi o brzini zagrijavanja zaključili da se radi o slijednim reakcijama te da nema reakcija grananja. Slaganje aktivacijske energije za dobivene modele s onima dobivenim Friedmanovom izokonverzijskom metodom $\left(E_{F R}\right)$ dobro je za sve kinetičke sheme, uzimajući u obzir konverzijska područja u kojima se kinetička shema primjenjuje. Kinetičke sheme zatim su međusobno uspoređene. Nakon međusobne usporedbe samo kinetička shema istraživača I2 zadovoljava statistički $F$-test (slika 9). Rezultati su prikazani u tablici 4. Dakle, proces toplinske razgradnje PVC-a započinje difuzijskim stupnjem (D4), zatim dolazi do autokatalitičke reakcije dehidrokloriranja i formiranja polienskih struktura. Te dvije vrste reakcija u prvom temeljnom stupnju opisuju se Cn kinetičkim modelima uz znatno različite aktivacijske energije. Drugi temeljni stupanj uključuje reakcije aromatizacije i intermolekulskog umrežavanja što se opisuje An i Fn kinetičkim modelima.

\section{Zaključak}

Temeljem dobivenih rezultata, može se nedvojbeno zaključiti da istraživači imaju značajan utjecaj na rezultate

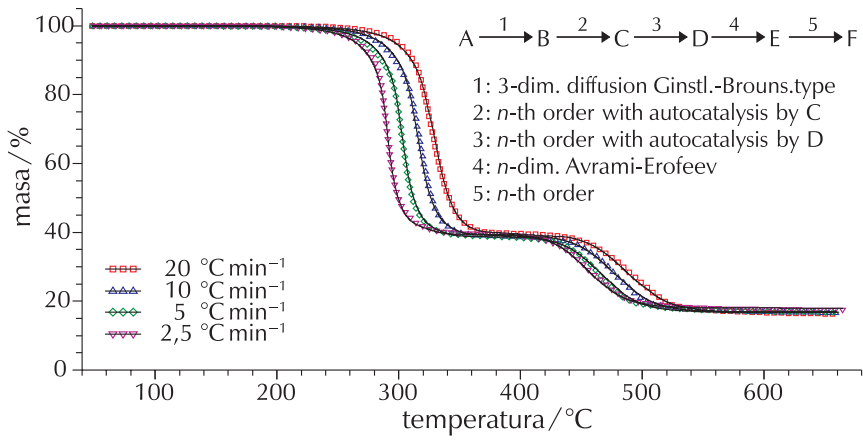

Slika 9 - Usporedba eksperimentalnih i izračunatih TG krivulja za PVC

Fig. 9 -Comparison of the experimental and calculated TG curves for PVC

kinetičke analize. Rezultati su pokazali da i u slučaju kada se radi o kinetički jednostavnom procesu, rezultati kinetičke analize nisu ujednačeni. Što je promatrani proces kinetički složeniji, razlike u rezultatima kinetičke analize su izraženije.

\section{Literatura \\ References}

1. S. Vyazovkin, A. K. Burnham, J. M. Criadoc, L. A. Pérez-Maqueda, C. Popescu, N. Sbirrazzuolie, ICTAC Kinetics Committee recommendations for performing kinetic computations on thermal analysis data, Thermochim. Acta 520 (2011) 1-19, doi: https://doi.org/10.1016/j.tca.2011.03.034.

2. A. Rogić, I. Čatić, D. Godec, Polimeri i polimerne tvorevine, Društvo za plastiku i gumu, 2008., str. 13.

3. S. Vyazovkin, Isoconversional Kinetics of Thermally Stimulated Processes, Springer, Cham, 2015.

4. H. L. Friedman, Kinetic of thermal degradation of char-form- 
ing plastics from thermogravimetry, Application to phenolic resin, J. Polym. Sci. Part C 6 (1963) 183-195, doi: https:// doi.org/10.1002/polc.5070060121.

5. N. Stipanelov Vrandečić, M. Erceg, B. Andričić, P. Ćerdić, Kinetička analiza izotermne razgradnje poli(etilen-oksida) modificiranog fenil hepta izobutil poliedarskim oligomernim silseskvioksanima, 69 (5-6) (2020) 261-268, doi: https:// doi.org/10.15255/KUI.2019.058.

6. Netzsch Thermokinetics Software Manual, Selb: Netzsch Gerätebau $\mathrm{GmbH} ; 2014$.

7. M. Erceg, I. Krešić, N. Stipanelov Vrandečić, M. Jakić, Different approaches to the kinetic analysis of thermal degradation of poly(ethylene oxide), J. Therm. Anal. Calorim. 131 (2018) 325-334, doi: https://doi.org/10.1007/s10973-017-6349-6.

8. N. Stipanelov Vrandečić, M. Erceg, M. Jakić, I. Klarić, Kinetic analysis of thermal degradation of poly(ethylene glycol) and poly(ethylene oxide)s of different molecular weight, Themochim. Acta 498 (2010) 71-80, doi: https://doi.org/10.1016/j. tca.2009.10.005.

9. S. L. Madorsky, S. Strauss, Thermal degradation of polyethyleneoxide and polypropylene oxide, J. Polym. Sci. 36 (1959) 183-194, doi: https://doi.org/10.1002/ pol.1959.1203613015.

10. N. Grassie, E. J. Murray, The thermal degradation of poly(-(D)- $\beta$-hydroxybutyric acid): part 3 - the reaction mechanism, Polym. Degrad. Stab. 6 (1984) 127-134, doi: https:// doi.org/10.1016/0141-3910(84)90032-6.
11. M. Erceg, Modificiranje svojstava biorazgradljivog poli(3-hidroksibutirata), Doktorski rad, Kemijsko-tehnološki fakultet u Splitu, Split, 2007.

12. M. Erceg, T. Kovačić, S. Perinović, Kinetic analysis of the non-isothermal degradation of poly(3-hydroxybutyrate) nanocomposites, Thermochim. Acta 476 (2008) 44-50, doi: https://doi.org/10.1016/j.tca.2008.07.009.

13. P. Budrugeac, Some methodological problems concerning the kinetic analysis of non-isothermal data for thermal and thermo-oxidative degradation of polymers and polymeric materials, Polym. Degrad. Stab. 89 (2005) 265-273, doi: https://doi.org/10.1016/j.polymdegradstab.2004.09.014

14. L. A. Pérez-Maqueda, J. M. Criado, F. J. Gotor, J. Málek, Advantages of Combined Kinetic Analysis of Experimental Data Obtained under Any Heating Profile, J. Phys. Chem. A 106 (2002) 2862-2868, doi: https://doi.org/10.1021/ jp012246b.

15. M. Erceg, I. Krešić, M. Jakić B. Andričić, Kinetic analysis of poly(ethylene oxide)/lithium montmorillonite nanocomposites, J. Therm. Anal. Calorim. 127 (2017) 789-797, doi: https://doi.org/10.1007/s10973-016-5413-y.

16. E. O. Elakesh, T. R. Hull, D. Price, P. Carty, Thermal decomposition of chlorinated poly(vinyl chloride) (CPVC), J. Vinyl Addit. Techn. 9 (2003) 116-126, doi: https://doi.org/10.1002/ vnl.10073.

17. M. Jakić, Studij međudjelovanja komponenata u polimernim mješavinama poli(vinil-klorid)/poli(etilen-oksid), Doktorski rad, Kemijsko-tehnološki fakultet u Splitu, Split, 2014.

\section{SUMMARY \\ Influence of Researchers on the Results of Kinetic Analysis of Thermal Degradation of Polymers \\ Matko Erceg, Miće Jakić, and Irena Krešić}

In this paper, the influence of researchers on the results of kinetic analysis of non-isothermal thermal decomposition of four polymers was investigated. Four polymers having different degrees of complexity of the degradation process were analysed. The kinetic analysis was performed by three researchers: one scientific advisor with tenure, one research associate and one doctoral student, all of whom used the same experimental thermogravimetric data. Kinetic analysis was performed using the Netzsch Thermokinetics Professional program. The results unequivocally showed that the researchers have a significant influence on the results of kinetic analysis, since they described the processes of the non-isothermal thermal decomposition of all samples by different kinetic schemes, and thus by different kinetic parameters.

\section{Keywords}

Kinetic analysis, non-isothermal thermogravimetry, influence of researcher

University of Split

Faculty of Chemistry and Technology

Ruđera Boškovića 35

21000 Split, Croatia
Original scientific paper

Received June 3, 2020

Accepted July 22, 2020 